\title{
N, P, Si budgets for the Red River Delta (northern Vietnam): how the delta affects river nutrient delivery to the sea
}

\author{
Thi Nguyet Minh Luu • Josette Garnier • \\ Gilles Billen • Thi Phuong Quynh Le • \\ Julien Nemery $\cdot$ Didier Orange $\cdot$ Lan Anh Le
}

Received: 7 June 2010/Accepted: 2 November 2010/Published online: 30 November 2010

(C) The Author(s) 2010. This article is published with open access at Springerlink.com

\begin{abstract}
The Red River Delta (RRD) (Vietnam), a region experiencing rapid population growth, industrialization, and economic development, concentrates $54 \%$ of the population of the whole Red River watershed in less than $10 \%$ of the basin area. Our study aimed at understanding and quantifying the processes by which the delta affects the nutrient fluxes coming from the upstream watershed before they reach the sea. A comprehensive budget of nitrogen $(\mathrm{N})$, phosphorus (P), and silica ( $\mathrm{Si}$ ) fluxes associated with natural and anthropogenic processes in the terrestrial and hydrological system of the delta was established
\end{abstract}

Electronic supplementary material The online version of this article (doi:10.1007/s10533-010-9549-8) contains supplementary material, which is available to authorized users.

T. N. M. Luu $(\varangle) \cdot$ J. Garnier · G. Billen

UMR 7619 Sisyphe, UPMC University Pierre \& Marie

Curie, Box 123, 4 place Jussieu, 75005 Paris, France

e-mail: minh.luu@upmc.fr

T. N. M. Luu · L. A. Le

Institute of Chemistry, Vietnamese Academy of Sciences

and Technology, 18 Hoang Quoc Viet, Cau Giay,

Hanoi, Vietnam

J. Garnier · G. Billen

CNRS, UMR 7619, UPMC Sisyphe Laboratory,

Box 123, 4 place Jussieu, 75005 Paris, France

T. P. Q. Le

Institute of Natural Product Chemistry, Vietnamese

Academy of Sciences and Technology, 18 Hoang Quoc

Viet, Cau Giay, Hanoi, Vietnam for five sub-basins of the delta for the period 2000-2006, based on official statistical data, available measurements, and our own sampling campaigns and enquiries. The results show that anthropogenic inputs of $\mathrm{N}$ and $\mathrm{P}$ brought into the delta area are higher than the amounts delivered by the river from the upstream watershed. However, the amounts of these two elements ultimately delivered to the coastal zone from the delta are lower than the amounts carried by the upstream river, showing extremely efficient retention of both the soils and the delta's drainage network. For Si (taking into account both dissolved and amorphous solid forms), the retention is much lower. High retention of $\mathrm{N}$ and $\mathrm{P}$ and low retention of $\mathrm{Si}$ in the delta area have up to now protected the coastal zone from severe eutrophication problems.

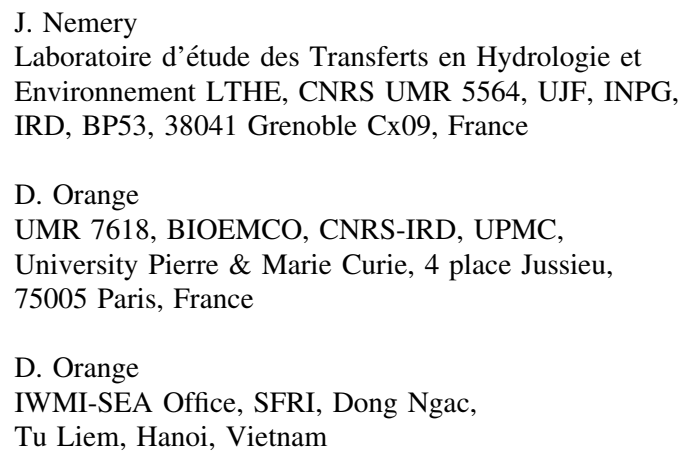


Keywords Red river - Delta $\cdot$ Nutrient budget .

Nitrogen · Phosphorus · Silica · Marine

eutrophication - ICEP indicator

\section{Introduction}

Nitrogen $(\mathrm{N})$, phosphorus $(\mathrm{P})$, and silica $(\mathrm{Si})$ are key elements in many biogeochemical processes and are regarded as limiting elements of both aquatic (Wetzel 1983) and terrestrial ecosystem processes (Chapin et al. 2002; Ramade 2009). Although they are basic natural constituents in aquatic ecosystems, excessive inputs of nutrients can significantly accelerate the processes of eutrophication, e.g., the development of algal blooms-sometimes harmful-and oxygen depletion (Wassmann and Olli 2004; Cugier et al. 2005; Billen et al. 2007; Diaz and Rosenberg 2008; Thieu et al. 2009). In terrestrial ecosystems, anthropogenic $\mathrm{N}$ inputs, either deliberately brought through cultivation of $\mathrm{N}$-fixing crops and application of industrial fertilizer or unintentionally coming through atmospheric deposition of $\mathrm{N}$ oxides generated by high-temperature combustion, are commonly reported as responsible for elevated $\mathrm{N}$ export to the coastal zone (Howarth et al. 1996; Boyer and Howarth 2008). The resulting increased nitrate contamination enhances the global denitrification rate and $\mathrm{N}_{2} \mathrm{O}$ emissions, which contribute to the greenhouse effect and the destruction of the stratospheric ozone layer (Crutzen and Ehhalt 1977; Bange 2000; Galloway and Cowling 2002; Van Drecht et al. 2003). Similarly, worldwide $\mathrm{P}$ mining and processing, mainly for fertilizer production, has reached a level on the same order of magnitude as natural weathering and erosion processes (Cordell et al. 2009). Regarding P point sources to surface water in European countries, phosphates in washing powders have contributed to doubling the per capita specific load, which increased from 2 gP capita- 1 day- 1 in the 1960 s to 4 gP capita- 1 day-1 in the 1980s, leading to eutrophication in stagnant and running water systems (see Vollenweider 1968; Billen et al. 2007). Si, essentially coming from rock weathering, is brought at a rate that depends on the hydrological and temperature regimes and is more often reduced than increased by anthropogenic activity (Sferratore et al. 2006). However, Si, which is often ignored in routine surveys, is a major component in the eutrophication problem, as the molar N:P:Si ratios need to be close to $16: 1: 16$ to avoid the proliferation of non-diatoms after exhaustion of Si by the normal new-production diatom growth phase (Turner et al. 2006; Billen and Garnier 2007). In most eutrophied river systems, a decrease in $\mathrm{Si}$ (due to damming or algal uptake) and an increase in $\mathrm{N}$ and $\mathrm{P}$ have resulted in the development of undesirable nondiatom algae, with adverse financial consequences on fisheries and tourism (Justic et al. 2002; Turner et al. 2006-Mississippi; Li et al. 2007-Yangtze; Knowler 2007; Yunev et al. 2007-Danube; Cugier et al. 2005-the English Channel; etc.).

In view of the importance of $\mathrm{N}, \mathrm{P}$, and $\mathrm{Si}$ for the functioning of terrestrial and aquatic environments, calculation of their budget is a useful approach to help maintain sustainable production, but also to better manage several environmental issues, such as acidification, hypoxia, eutrophication, and climate change (FAO 2003; Wassmann and Olli 2004; Diaz and Rosenberg 2008; Rabouille et al. 2008).

In Southeast Asia, the population concentrates mostly in large deltas where anthropogenic pressure is very high, leading to $\mathrm{N}$ and $\mathrm{P}$ pollution by agriculture, industries, and domestic effluents, most often released with no treatment (Le et al. 2005; Ngo et al. 2007). Vietnam has two major deltas, the Red River Delta (RRD) in the north and the Mekong Delta in the south. The present study focuses on the former, which plays an important role in the country's agricultural, industrial, and economic development. It is a good example of a region with rapid population growth, industrialization, and economic development leading to increased resource consumption and environmental degradation.

Numerous studies have dealt with the establishment of the $\mathrm{N}$ and/or P budget in regional watersheds in the northern United States and in Europe (Howarth et al. 1996; Garnier et al. 1999, 2002; Faerge et al. 2001; Boyer et al. 2002; Némery and Garnier 2007a, b; Boyer and Howarth 2008), as well as, more recently, in tropical hydrographic networks in Asia and Africa (Buranapratheprat et al. 2002; Le et al. 2005; Baker et al. 2007). Budgets focusing on deltas are still scarce, and even more so when including $\mathrm{Si}$, in addition to $\mathrm{N}$ and $\mathrm{P}$. There have been only a few attempts toward estimation of the Si budget in such regions (Le et al. 2010; Moon et al. 2007).

The aim of this study is to inventory the sources and sink of nutrients $(\mathrm{N}, \mathrm{P}, \mathrm{Si})$ in the terrestrial and 
aquatic components of the RRD. This is a follow-up to Le et al. (2005) budget of the upstream watershed of the Red River, taking into account in greater detail the specific processes occurring in the delta area at the land-sea interface. As we did in a previous study dealing with the hydrological budget (Luu et al. 2010), five sub-basins were distinguished within the delta to take into account the contrasting dominant land uses (i.e., paddy rice fields in the lower Red River sub-basin and the Day estuary, or forest in the Boi sub-basin) and the heterogeneous distribution of the population (varying from 260 inhabitants $\mathrm{km}^{-2}$ in the Boi sub-basin to 1,700 inhabitants $\mathrm{km}^{-2}$ in the Bui sub-basin). Our purpose was to evaluate the role of the delta as a source or sink for the nutrient fluxes delivered by the upstream watershed before they reach the sea, taking into account the landscape heterogeneities in the delta.

\section{Study site: the red river delta}

Geomorphologic and hydrological characteristics

The RRD is located in the northern part of Vietnam in the lower plain of the Red River catchments. The RRD area extends over $14,300 \mathrm{~km}^{2}$ entirely situated below $3 \mathrm{~m}$ above sea level and much of it does not rise more than $1 \mathrm{~m}$ above sea level. It is limited landwards by Son Tay city in the northwest (on the Red River, $150 \mathrm{~km}$ from the sea), and seawards by the coastline extending over $360 \mathrm{~km}$ from Hai Phong province in the northeast to Ninh Binh province in the south (Fig. 1a).

The RRD is rich in natural resources and plays an important role in the socioeconomic development of the two main cities in Vietnam (the capital Hanoi and the industrial city of Hai Phong).

The hydrographical system in the RRD represents a complex network not only in terms of morphology, but also in terms of their hydrological regimes. The fluvial network of the delta is quite dense (density about 2-4 $\mathrm{km} \mathrm{km}^{-2}$ ) (Tran 2007).

The total length of the main Red River course is about $1,126 \mathrm{~km}$ from the source in China to the mouth (Ba Lat estuary), of which the main branch of the Red River in the delta accounts for $216 \mathrm{~km}$ (Tran 2007). The main Red River branch enters the delta at Son Tay, and then divides into two distributaries: the
Day River on the right side and the Duong River on the left. On the left side of the Red River (see Fig. 1a), the Thai Binh River, about $100 \mathrm{~km}$ long, starts at the confluence of three rivers: the Cau, Thuong, and Luc Nam. The Thai Binh River (64 km) is joined by the Red River through the Duong River (upstream) and the Luoc River (downstream). The Day River drains the right part of the RRD; it has a length of $240 \mathrm{~km}$ and a total watershed area of approximately $8,500 \mathrm{~km}^{2}$. The Nhue River is supplied by water from the Red River through the Lien Mac sluice and joins the Day River at Phu Ly town; the river is approximately $75 \mathrm{~km}$ long. Two other major interconnecting rivers between the Day River and the Red River are the Chau and the Dao Rivers. There are also several tributaries and streams in the delta. Both the Red River and Thai Binh River systems including the Day River deliver a total volume of about $100 \mathrm{~km}^{3}$ year ${ }^{-1}$ (Luu et al. 2010).

Land use, social and economic conditions

It is estimated that in 2006, $16,600,000$ people were living in the RRD (General Statistic Office 2006) (Table 1). The current annual growth rate of the population is as high as $3 \%$. The population density, 1,160 inhabitants $\mathrm{km}^{-2}$ (Fig. 2a), is five times the national average (225 inhabitants $\mathrm{km}^{-2}$ ). Of the entire population, $78 \%$ live in rural areas, but the number of people living in urban areas is increasing rapidly (from 3.3 million in 2000 to 3.6 million in 2006), especially in the Hanoi metropolitan area, leading to a strong increase in consumption of natural resources and energy and in production of wastes.

Figure $2 \mathrm{~b}$ shows the present land use in RRD. About $47 \%$ of the area is used as agricultural and aquacultural land; of this, $90 \%\left(6,700 \mathrm{~km}^{2}\right)$ is used for annual crops, $6.6 \%$ for aquaculture and fisheries, $3.1 \%$ for perennial crops, and $0.6 \%$ as pasture area. Only $13 \%\left(2,000 \mathrm{~km}^{2}\right)$ is classified as forest area, situated mostly in the western side of the RRD (Hoa Binh province). Housing, industry, roads, and canals occupy $21 \%$ of the RRD total area, while about $12 \%$ are water surfaces (rivers, lakes, etc.) (Nguyen et al. 1995; General Statistic Office 2006), (Table 2).

The main income in most provinces within the RRD is from agriculture. About $80 \%$ of the population is still engaged in the agricultural sector. In recent years, the economic structure in the basin has 


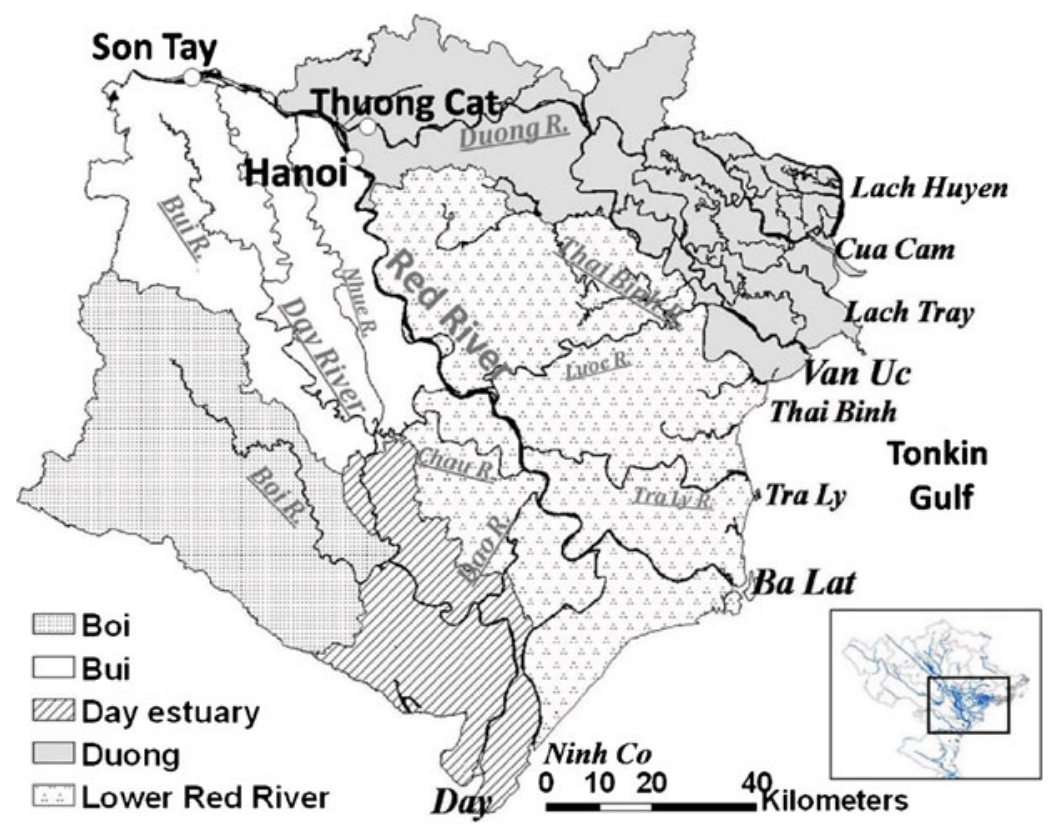

(a)

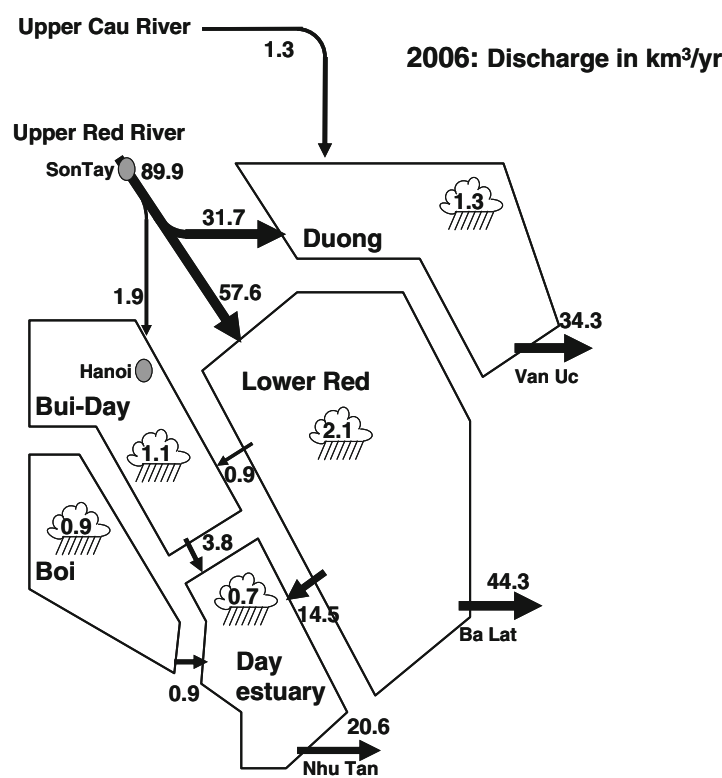

(b)

Fig. 1 a Hydrographic network of the RRD and situation of the RRD in northern Vietnam. b Water fluxes in 2006 for the five sub-basins considered in the RRD (Luu et al. 2010) used

been changing significantly. Employment has gradually been reduced in the agricultural sector and shifted to industry and service sectors, causing a large migration from rural areas to urban ones.

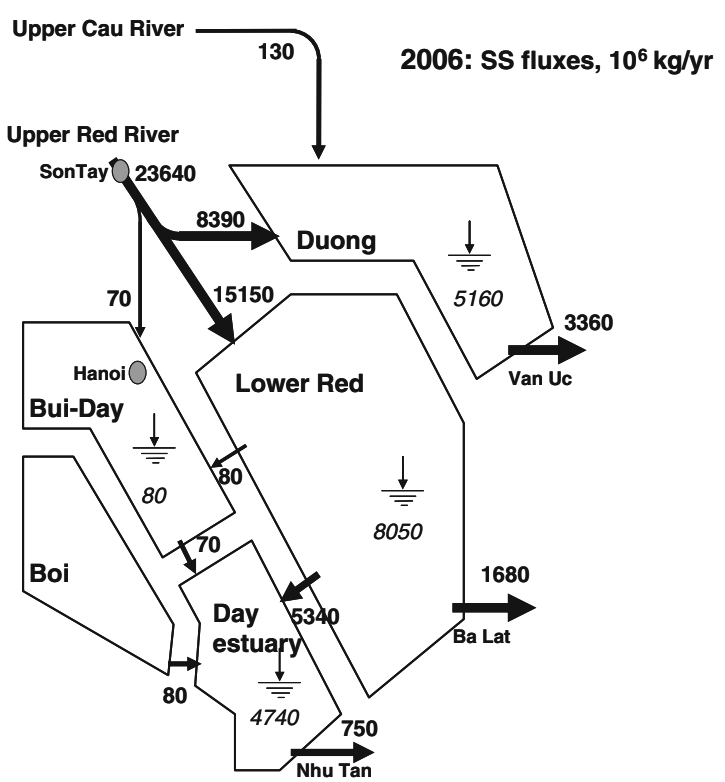

(c)

for the calculation of SS, N, P, Si fluxes. c SS for the year 2006. $\downarrow$ indicates the amount of SS retention in the sub-basins

Meteorological conditions

The RRD is located within a typical wet, hot, subtropical climate determined by monsoons. In winter, 
Table 1 Population within the five sub-basins of the RRD in 2006

\begin{tabular}{|c|c|c|c|c|c|c|}
\hline \multirow[t]{2}{*}{ Sub-basins } & \multirow[t]{2}{*}{ Area $\left(\mathrm{km}^{2}\right)$} & \multirow{2}{*}{$\begin{array}{l}\text { Discharge } \\
\left(\mathrm{km}^{3}\right)\end{array}$} & \multicolumn{3}{|c|}{ Population 2006} & \multirow{2}{*}{$\begin{array}{l}\text { Density } \\
\left(\text { inhab } \mathrm{km}^{-2}\right)\end{array}$} \\
\hline & & & Total & Urbain & Rural & \\
\hline Bui-Day & 2,751 & 3.8 & $4,818,128$ & $1,979,286$ & $2,838,842$ & 1,751 \\
\hline Boi & 2,473 & 0.9 & 647,595 & 27,838 & 619,757 & 262 \\
\hline Day,estuary & 1,413 & 20.6 & $1,229,909$ & 130,073 & $1,099,836$ & 870 \\
\hline Lower Red River & 4,773 & 44.3 & $5,705,763$ & 532,519 & $5,173,244$ & 1,195 \\
\hline Duong & 2,902 & 34.3 & $4,199,395$ & 914,971 & $3,284,424$ & 1,447 \\
\hline Whole delta & 14,312 & 99.2 & $16,600,790$ & $3,584,687$ & $13,016,103$ & 1,160 \\
\hline
\end{tabular}

the weather is quite cold with little rain, and summer is hot, sunny and rainy. The average annual rainfall is approximately $1,600 \mathrm{~mm}$. The highest rainy season occurs from May to October, and most rainfalls are heavy showers which characterize upstream catchments of the rivers and the RRD as well. Summer rainfall accounts for $80-85 \%$ of total annual precipitation. Average temperatures range from $8^{\circ} \mathrm{C}$ in December and January, the coolest months, to more than $37^{\circ} \mathrm{C}$ in April, the hottest month. The daily average of 3.1 sunshine hours falls to only $1.3 \mathrm{~h}$ in March and maximum sunshine duration (up to $12 \mathrm{~h}$ per day) often occurs in June. Mean humidity is greater than $80 \%$ throughout the year (IMHE - MONRE 1996-2006).

\section{Materials and methods}

\section{Chemical analysis}

Water discharge at the outlet of the five sub-basins was reported by Luu et al. (2010). In order to investigate the water quality, routine surveys were carried out at monthly intervals from 2006 to 2008 at the outlet of each sub-basin. In this report, for the Duong and lower Red River sub-basins, we consider their estuarine branches as one outlet to the sea only.

Concerning waste water from industrial and agricultural activities, several samples were taken from various industrial sectors around Hanoi; water flowing from paddy fields and from some of the mainly dry crops was collected on several occasions from April to June 2007 in order to evaluate the diffuse source pollution from different types of land use.

During sampling campaigns, the physical-chemical parameters were measured by a Hydrolab 4a multiparameter probe [temperature $\left({ }^{\circ} \mathrm{C}\right), \mathrm{pH}$, conductivity $\left(\mu \mathrm{S} \mathrm{cm}^{-1}\right)$, salinity (\%o), turbidity (NTU), redox potential $(\mathrm{mV})$ and DO (dissolved oxygen, $\left.\mathrm{mg}^{-1}\right)$ ], but not reported here.

Each water sample was collected in a 1-1 polyethylene recipient then was kept at $4{ }^{\circ} \mathrm{C}$ in an icebox during transportation to the laboratory where water was filtered through $\mathrm{GF} / \mathrm{F}$ membrane filters (Whatman, $0.7 \mu \mathrm{m}$ porosity) and frozen.

\section{Particles}

Suspended solid (SS) values were determined as the weight of material retained on the Whatman GF/F membrane per volume unit after drying the filter for $2 \mathrm{~h}$ at $120^{\circ} \mathrm{C}$. Values correlate well with NTU (not shown). Biogenic $\mathrm{Si}$ in riverine particulate matters collected on Whatman cellulose nitrate membranes was measured using wet alkaline extraction techniques (Ragueneau and Treguer 1994; Conley et al. 1989; Conley 1998, 2002). Total P was analyzed using unfiltered frozen water samples. The concentration expressed in $\mathrm{mg} \mathrm{P}-\mathrm{PO}_{4} \mathrm{l}^{-1}$ was determined (see below) after persulfate digestion with sulfuric acid (AFNOR 1982). Total particulate P (TP) was also determined on concentrated suspended sediments (Némery and Garnier 2007a) with a high temperature/ $\mathrm{HCl}$ extraction technique.

\section{Dissolved elements}

Nitrate, nitrite, and ammonium were determined spectrophotometrically in the filtered water samples with a Quaatro (Bran + Luebbe) flow-through spectrophotometric apparatus using standard procedures (Jones 1984; Slawyck and McIsaac 1972): ammonium reacted with salicylate and dichloro-isocyanuric 
Fig. 2 a Population density (inhabitants $\mathrm{km}^{-2}$ ); b Land use in the RRD

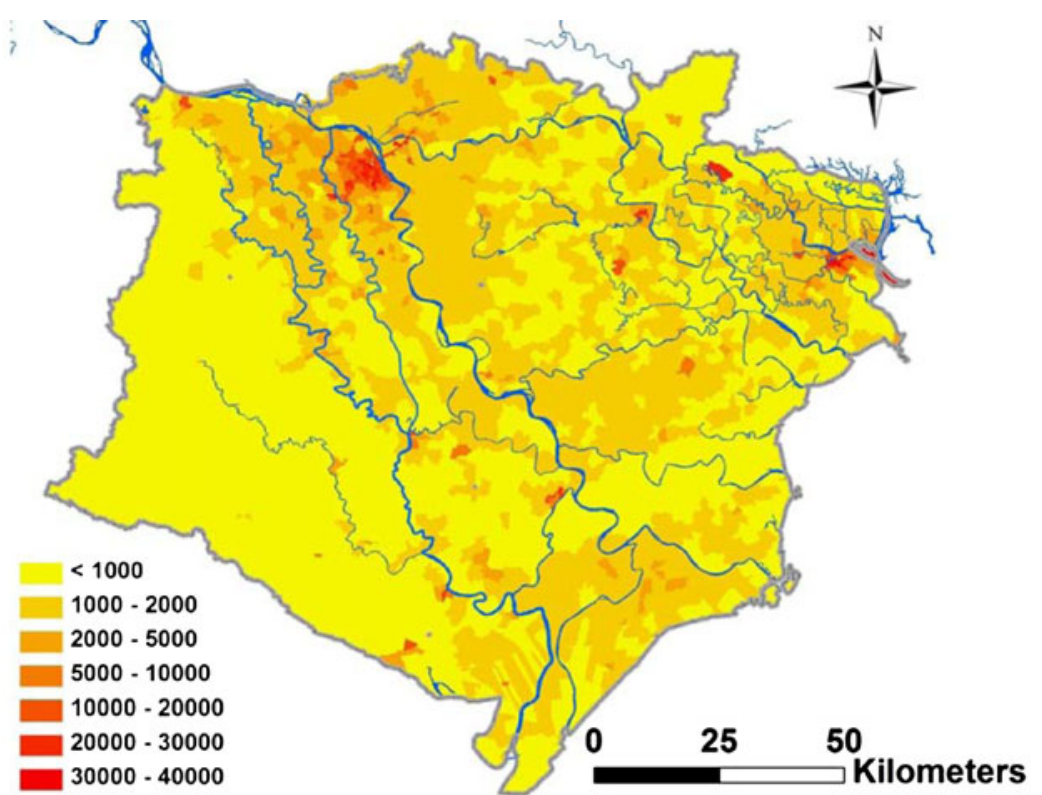

(a)

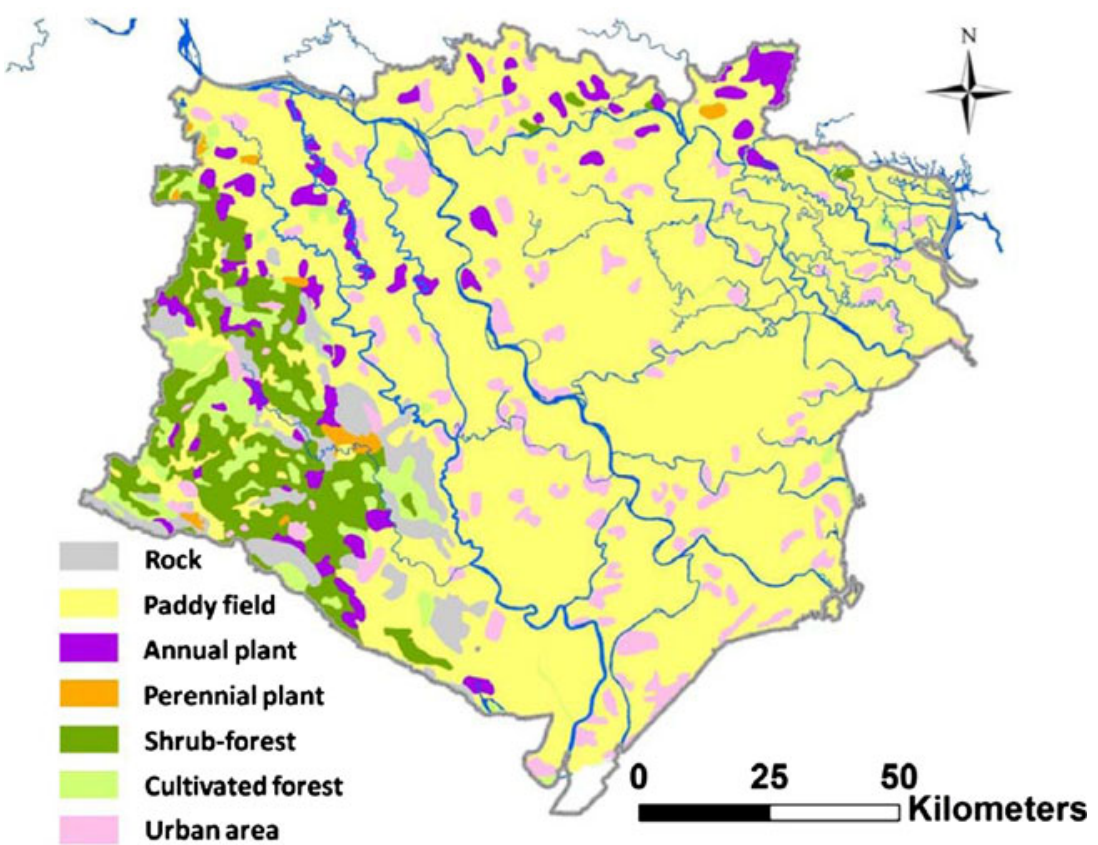

(b) acid, using nitroprusside as a catalyst, to produce a blue compound measured at $660 \mathrm{~nm}$; nitrite reacted under acidic conditions with sulfanilamide to form a diazo-compound that then couples with $N$-(1-naphtyl)ethylenediamine to form a reddish-purple azo-dye that is measured at $550 \mathrm{~nm}$; nitrate was determined after reduction into nitrite. Ortho-phosphate from filtered water samples was reacted with molybdate and ascorbic acid in the presence of antimony potassium tartrate to form a blue compound measured at $880 \mathrm{~nm}$; total $\mathrm{P}$ was determined on unfiltered water after sodium persulfate digestion and mineralization at $110^{\circ} \mathrm{C}$ in an acidic phase (Eberlein and Katter 1984). Dissolved silica (DSi) was determined by 
Table 2 Distribution of land-use within the five sub-basins of RRD (in $\mathrm{km}^{2}$ ) in 2006

\begin{tabular}{|c|c|c|c|c|c|c|c|c|c|}
\hline \multirow[t]{2}{*}{ Sub-basins } & \multicolumn{4}{|c|}{ Agricultural soil } & \multirow[t]{2}{*}{ Forest } & \multirow[t]{2}{*}{ Urban area } & \multicolumn{2}{|l|}{ Water surface } & \multirow{2}{*}{$\begin{array}{l}\text { Unused } \\
\text { land }\end{array}$} \\
\hline & $\begin{array}{l}\text { Paddy } \\
\text { Land }\end{array}$ & $\begin{array}{l}\text { Annual } \\
\text { plants }\end{array}$ & $\begin{array}{l}\text { Perennial } \\
\text { plants }\end{array}$ & Grassland & & & Aquaculture & $\begin{array}{l}\text { Rivers, lakes, } \\
\text { flooded area }\end{array}$ & \\
\hline Bui-Day & 985 & 148 & 124 & 3 & 373 & 662 & 79 & 202 & 174 \\
\hline Boi & 333 & 105 & 62 & 4 & 1,041 & 253 & 29 & 95 & 551 \\
\hline Day estuary & 594 & 55 & 70 & 3 & 151 & 260 & 77 & 70 & 134 \\
\hline Lower Red River & 2,397 & 179 & 219 & 0 & 143 & 1,046 & 288 & 409 & 92 \\
\hline Duong & 1,137 & 81 & 127 & 1 & 209 & 812 & 177 & 309 & 51 \\
\hline Whole delta & 5446 & 568 & 602 & 11 & 1,916 & 3,032 & 650 & 1,084 & 1,002 \\
\hline
\end{tabular}

spectrophotometry and analyzed from filtered water samples (Rodier 1984).

Questionnaire and statistics

When investigating the industrial wastewater, we gathered information on representative enterprises within the RRD concerning their production, discharge of effluents, and water quality variables such as $\mathrm{pH}, \mathrm{SS}$, dissolved oxygen (DO), biological oxygen demand (BOD), chemical oxygen demand (COD), and nutrients $\left(\mathrm{NO}_{3}, \mathrm{NO}_{2}, \mathrm{NH}_{4}\right.$, total $\mathrm{N}, \mathrm{PO}_{4}$, total $\left.\mathrm{P}\right)$. Our approach involved (i) the establishment of a census of businesses using official inventories and "yellow pages" for the factory address, (ii) elaboration of a questionnaire sent to all registered companies, (iii) sampling effluents from a number of factories for which we performed the chemical analyses mentioned above. Our efforts were limited to the 11 provinces in the delta and to the most significant sectors of activity in terms of organic and nutrient pollution: the food and textile industries, the chemical industry, the wood and paper industry, and hospitals.

The questionnaire was constructed and sent to about 600 businesses, with the request to tick an appropriate box, (i) to document the size of the companies (range of wastewater effluent in $\mathrm{m}^{3} \mathrm{~s}^{-1}$; number of workers; range of production in tons day $^{-1}$ ); (ii) the quality of the wastewater discharged (ranges of values for variables such as SS, BOD, total $\mathrm{N}$ and total $\mathrm{P}$ ); and (iii) how effluents were discharged (into the river, into a canal, into a lake or a pond, spread on land, or stored in a basin). We received approximately 60 answers, which we consider a reasonably good return rate.
Statistical data such as population, land use, livestock, agricultural production, etc., were collected from the General Statistic Office (2006) and then analyzed in detail as presented in Supplementary Information.

Daily SS was obtained from the IMHE (Institute of Meteorology and Hydrology 1996-2006) at the entrance of the delta at Son Tay and the entrance of the lower Red River and Duong sub-basins (Fig. 1b, c). At the other locations, our own measurements were used.

Nutrient and suspended solid flux calculations

Dissolved nutrient fluxes, e.g., $\mathrm{N}\left(\mathrm{TN}_{\text {inog: }} \Sigma \mathrm{N}-\right.$ $\left.\mathrm{NO}_{2}+\mathrm{N}-\mathrm{NO}_{3}+\mathrm{N}-\mathrm{NH}_{4}\right), \quad \mathrm{P} \quad\left(\mathrm{P}-\mathrm{PO}_{4}\right)$, and $\mathrm{Si}$ (DSi), were calculated at the inlet and the outlet of the five sub-basins on the basis of the water budget as established by Luu et al. (2010), (see Fig. 1b, c), and the mean annual concentrations of DSi and $\mathrm{P}-\mathrm{PO}_{4}$, measured in the field or taken from the literature (Kurosawa et al. 2006; Le et al. 2005, 2010; IMHE MONRE 1996-2006; Nguyen et al. 2005; Trinh et al. 2006; Tran et al. 2006)

Flx $\left(10^{6} \mathrm{~kg} \mathrm{year}^{-1}\right)=\frac{Q m \times C m \times 3,600 \times 24 \times 365}{10^{9}}$

Where Flx is the nutrient flux of $\mathrm{DSi}, \mathrm{TN}_{\mathrm{inog}}$ or ${\mathrm{P}-\mathrm{PO}_{4} \text { in } 10^{6} \mathrm{~kg} \text { year }}^{-1}, Q m$, is the mean annual discharge for the recorded period $\left(\mathrm{m}^{3} \mathrm{~s}^{-1}\right)$ and $\mathrm{Cm}$, is the mean annual concentrations $\left(\mathrm{mg}^{-1}\right.$ or $\left.\mathrm{g} \mathrm{m}^{-3}\right)$.

For SS, the annual flux $\left(10^{6} \mathrm{~kg}\right.$ year $\left.^{-1}\right)$ was determined for the year 2006 by multiplying the mean annual water fluxes $\left(\mathrm{m}^{3}\right.$ year $\left.^{-1}\right)$ by discharge weighted mean concentration $\left(\mathrm{g} \mathrm{m}^{-3}\right)$ according to 
the load estimation procedure described by Verhoff et al. (1980)

$$
\begin{aligned}
& \text { Flx }\left(10^{6} \mathrm{~kg} \mathrm{year}^{-1}\right)=\frac{\left[\sum \mathrm{CiQi}\right]}{\sum_{3 \mathrm{Q} i}} \times Q m \times 3,600 \times 24 \\
& \times 365 \times 10^{-9}
\end{aligned}
$$

Where Flx is the SS flux in $10^{6} \mathrm{~kg}_{\text {year }}{ }^{-1}, \mathrm{Ci}$ is the discrete instantaneous concentration $\left(\mathrm{g} \mathrm{SS} \mathrm{m}^{-3}\right)$, $Q i$ is the corresponding instantaneous discharge $\left(\mathrm{m}^{3} \mathrm{~s}^{-1}\right)$ and $Q m$ is the mean discharge for period of record $\left(\mathrm{m}^{3} \mathrm{~s}^{-1}\right)$.

Good-quality daily measurements of SS at Son Tay station were available. Daily measurements were also available at Hanoi station (main Red River branch) and Thuong Cat (Duong entrance). However, due to the location of these sampling stations close to the bank, these SS data seem to be overestimated (as has been confirmed by measurements along a transversal profile of the river), so that we preferred to calculate the entering SS fluxes on the basis of the SS flux at Son Tay station and the water fluxes at the entrance of the Duong and the Red River's main branch (Fig. 1c).

Particulate $\mathrm{P}$ and $\mathrm{Si}$ (ASi: amorphous silica) fluxes were calculated from the SS fluxes and the $\mathrm{P}$ or $\mathrm{Si}$ content of SS. Total P (TP) and total Si (TSi) fluxes are the sum of the particulate and dissolved fraction. The dissolved inorganic $\mathrm{N}$ fluxes $\left(\mathrm{TN}_{\text {inorg }}\right)$ are represented by the sum of the components $\mathrm{N}-\mathrm{NO}_{2}$, $\mathrm{N}-\mathrm{NO}_{3}, \mathrm{~N}-\mathrm{NH}_{4}$, whereas the total organic $\mathrm{N}$ concentration (TON, $\mathrm{mg} \mathrm{N}^{-1}$ ) was calculated from the linear relation with suspended solids $\left(\mathrm{SS}, \mathrm{mg}^{-1}\right)$, established by Le et al. (2005), TON $=0.4+$ 0.0013. SS $\left(r^{2}=0.91\right)$. TN is calculated as the sum $\mathrm{TN}_{\text {inorg }}$ and TON.

Nutrient and suspended solid budget for the five sub-basins

To determine a semi-distributed SS and nutrient budget as we did for water flow (Luu et al. 2010), the RRD was subdivided into five sub-basins, distinguished by their population density (from 260 inhabitants $\mathrm{km}^{-2}$ in Boi sub-basin to 1,700 inhabitants $\mathrm{km}^{-2}$ in Bui sub-basin), (Fig. 2a) or by their land use (predominantly paddy soil in the lower Red River sub-basin and Day estuary or forest in the Boi subbasin), (Fig. 2b). We distinguish the soil budgets from the water budgets because the sources and the nature of the data are different-statistical for the former, experimental for the latter.

\section{Budget of the soil system}

All the data such as land use, livestock, agricultural production, and industrial activities, are available at the district level; the data for each sub-basin were calculated from the district data as pro rata of the surface area located within each sub-basin.

The soil nutrient balance is usually defined as the difference between nutrient inputs (atmospheric deposition, $\mathrm{N}$ fixation, fertilizer application, and input of animal manure) and export (harvesting, grazing by domestic animals, leaching/erosion, and denitrification as far as $\mathrm{N}$ is concerned). The data used for estimating each of these terms are described in Supplementary Information. If the balance for a particular nutrient is positive, that nutrient will accumulate in the soil. In contrast, if the balance is negative, depletion occurs, and the soil fertility status may deteriorate. Internal nutrient cycling (microbial uptake and decomposition) is not considered in the budget (Akaselsson et al. 2007; FAO 2003, 2005; Smil 1999).

\section{Budget of the hydrological network}

Suspended solids and nutrients are introduced to surface waters from diffuse and point sources; they may also be retained or eliminated through various processes during their transfer to the sea. The approach for assessing diffuse sources relies on the total annual specific water flux (difference between rainfall and evapotranspiration) for each sub-basin as established by Luu et al. (2010) (see Fig. 1b). Nutrient concentration in runoff from each land use type was evaluated from direct measurements and from the literature (Kurosawa et al. 2006; Wosten et al. 2003). Point sources were estimated from population data and industrial census. (See Supplementary Information for details.)

\section{Sources of error and uncertainty}

Three sources of data (assembled from the literature, derived from official statistics, and deduced from direct measurement) as well as several assumptions 
were combined in the calculation of the nutrient balances, which are therefore subject to a number of possible biases. Several fluxes were not taken into account in the balance. Nutrient losses by volatilization, which are very difficult to estimate, have been ignored at this stage (see Tables 4, 5, 6). Fluxes of atmospheric deposition and $\mathrm{N}$ fixation which, although site-specific, were estimated from the literature data for similar regions, due to the lack of direct measurement data. Further, nutrient removal in the harvested product is usually calculated from the average nutrient content per ton of product, but nutrient concentrations in the product tend to increase with increasing yield (FAO 2006; Faerge et al. 2001). This may result in a nutrient content not linearly related to yield, and a nutrient removal being overestimated when yields are low or vice versa.
Although we cannot assess the reliability of official statistical data, it is clear that biases might have been introduced in the budget calculation, when some data provided at the district level were extrapolated from the country level. Finally, in terms of our field measurements, the frequency of investigation in space and in time, water sampling, and chemical analysis are all sources of variation.

While we acknowledge multiple sources of uncertainty in our data, our approach is advantageous for its ability to (i) test the coherence among the various sources of data, (ii) compare the soil agricultural budgets with the hydrological budgets, and (iii) better understand the biogeochemical functioning of various sectors of the delta differing according to their land use and human activities, as we can expect that the errors on each flux are of the same nature.

Table 3 Agricultural production and its destination (human and livestock consumption or exportation) in the RRD

\begin{tabular}{|c|c|c|c|c|c|c|c|}
\hline \multirow[t]{2}{*}{2006} & \multirow[t]{2}{*}{$\% \mathrm{~N}$} & \multirow[t]{2}{*}{$\% \mathrm{P}$} & \multirow[t]{2}{*}{$\% \mathrm{Si}$} & \multicolumn{4}{|l|}{ Delta } \\
\hline & & & & $\begin{array}{l}\text { Production } \\
\left(\text { Kt year }^{-1}\right)\end{array}$ & $\begin{array}{l}\text { Human consump. } \\
\left(\mathrm{Kt} \mathrm{year}^{-1}\right)\end{array}$ & $\begin{array}{l}\text { Animal cons. } \\
\left(\mathrm{Kt} \mathrm{year}^{-1}\right)\end{array}$ & $\begin{array}{l}\text { Export/import } \\
\left(\text { Kt year }^{-1}\right)\end{array}$ \\
\hline \multicolumn{8}{|l|}{ Rice } \\
\hline Grain & 1.3 & 0.22 & 0.0200 & 5,852 & 2,806 & 1,127 & 1,919 \\
\hline Leaves & 1.3 & 0.22 & & 5,852 & 0 & 5,852 & 0 \\
\hline \multicolumn{8}{|l|}{ Maïze } \\
\hline Grain & 1.4 & 0.35 & 0.0010 & 287 & 133 & 143 & 11 \\
\hline Leaves & 1.4 & 0.35 & & 574 & 0 & 574 & 0 \\
\hline Wheat & 1.9 & 0.48 & 0.0150 & 0 & 166 & 0 & -166 \\
\hline Soja & 3.5 & 0.46 & 0.0010 & 85 & 17 & 63 & 6 \\
\hline Starchy roots & 0.3 & 0.12 & 0.0010 & 372 & 249 & 107 & 16 \\
\hline Leaves & 0.3 & 0.22 & & 186 & 0 & 186 & 0 \\
\hline Vegetables & 0.2 & 0.06 & 0.0010 & 347 & 1,378 & 0 & -1031 \\
\hline Fruits & 0.1 & 0.09 & 0.0050 & 245 & 531 & 0 & -286 \\
\hline Sugar cane & 0.2 & 0.08 & 0.0200 & 269 & 266 & 109 & -106 \\
\hline Leaves & 0.2 & 0.08 & & 54 & 0 & 54 & 0 \\
\hline Peanuts & 4.0 & 0.23 & 0.0010 & 66 & 17 & 0 & 50 \\
\hline Tea, coffee... & 2.9 & 0.15 & 0.0002 & 0 & 8 & 0 & -8 \\
\hline Grass & 2.0 & 0.26 & & 189 & 0 & 189 & 0 \\
\hline Other feed & 2.0 & 0.3 & & 170 & 0 & 670 & -500 \\
\hline Meat and dairy pdcts & 3.5 & 0.3 & 0.0010 & 684 & 498 & 0 & 186 \\
\hline Fish and sea food & 3.5 & 0.3 & 0.0015 & 313 & 282 & & 31 \\
\hline Total in $10^{6} \mathrm{~kg} \mathrm{~N}$ year ${ }^{-1}$ & & & & 215.2 & 74.8 & 121.4 & 19 \\
\hline Total in $10^{6} \mathrm{~kg}$ P year ${ }^{-1}$ & & & & 34.8 & 11.7 & 21.3 & 2 \\
\hline Total in $10^{6} \mathrm{~kg} \mathrm{Si}$ year ${ }^{-1}$ & & & & 1.3 & 0.7 & 0.3 & 0.3 \\
\hline
\end{tabular}




\section{Results and discussion}

\section{Nutrient budgets}

The nutrient budgets are summarized in Tables 3, 4, 5 and 6 for each of the five sub-basins and for the whole delta, for each of the three elements $(\mathrm{N}, \mathrm{P}, \mathrm{Si})$.

Since the surface areas of the Bui sub-basin and the Boi sub-basin are similar, we have focused on these two contrasted sub-basins in terms of land use and population density to illustrate the processes involved in the $\mathrm{N}$ cycle (Figs. 3a, b). In the Bui subbasin, agriculture soils (paddy fields) are prominent, while in the Boi sub-basin, forest dominates, which results in a clear difference in the quantity of fertilizer applied (7.4 vs. $1.610^{6} \mathrm{~kg} \mathrm{~N}_{\text {year }}{ }^{-1}$, respectively) and to a much higher $\mathrm{N}$ retention or rather elimination by denitrification in the former than in the latter basin. In the Boi sub-basin, with a rather small population, agricultural production is slightly greater than the local consumption of agricultural products by humans and livestock $(13.6 \times 10$ and $10.5 \times$ $10^{6} \mathrm{~kg} \mathrm{~N}$ year $^{-1}$, respectively): this sub-basin can therefore be considered as a net exporter of agricultural products and their contained nutrients (Le et al. 2005; Billen et al. 2005 and 2007). On the contrary,

Table 4 Nitrogen budgets of the sub-basins of the RRD (units are $10^{6} \mathrm{~kg}^{\mathrm{TN}}$ year ${ }^{-1}$ )

\begin{tabular}{|c|c|c|c|c|c|c|}
\hline $\mathrm{TN}, 10^{6} \mathrm{~kg} \mathrm{year}^{-1}$ & Bui SB & Boi SB & $\begin{array}{l}\text { Day } \\
\text { estuary SB }\end{array}$ & $\begin{array}{l}\text { Lower Red } \\
\text { River SB }\end{array}$ & Duong SB & $\begin{array}{l}\text { Total } \\
\text { RRD }\end{array}$ \\
\hline Area $\left(\mathrm{km}^{2}\right)$ & 2,751 & 2,473 & 1,413 & 4,773 & 2,902 & 14,312 \\
\hline \multicolumn{7}{|l|}{ Soil system } \\
\hline \multicolumn{7}{|l|}{ Atmosph. deposition } \\
\hline Forest & 0.2 & 0.5 & 0.1 & 0.1 & 0.1 & 1 \\
\hline Agriculture & 1.2 & 0.7 & 0.6 & 2.3 & 1.4 & 6.2 \\
\hline \multicolumn{7}{|l|}{ Nitrogen fixation } \\
\hline Forest & 0.2 & 0.5 & 0.1 & 0.1 & 0.1 & 1 \\
\hline Grassland and cropland & 7.4 & 1.6 & 3 & 13.2 & 6 & 31.1 \\
\hline Fertilizer application & 24.4 & 9.7 & 13.7 & 56.6 & 27.6 & 132 \\
\hline \multicolumn{7}{|l|}{ Cattle farming and aqua-culture } \\
\hline Meat and dairy production & 6.0 & 0.8 & 1.4 & 9.2 & 6.5 & 23.9 \\
\hline Excretion & 20.4 & 8.9 & 7.5 & 35.1 & 22.4 & 94.3 \\
\hline Grazing and feed consumption & 23.8 & 7.6 & 9.9 & 52.1 & 27.9 & 121.4 \\
\hline \multicolumn{7}{|l|}{ Agriculture and food balance } \\
\hline Agricultural production & 40.4 & 13.6 & 21.6 & 94.1 & 45.5 & 215.2 \\
\hline Net commercial export & -5.2 & 3.0 & 6.2 & 16.3 & -1.3 & 18.9 \\
\hline Human consumption & 21.7 & 2.9 & 5.6 & 25.7 & 18.9 & 74.9 \\
\hline \multicolumn{7}{|l|}{ Hydrosystem } \\
\hline \multicolumn{7}{|l|}{ Inputs to the hydrosystem } \\
\hline Domestic wastewater release & 20.1 & 1.1 & 4.0 & 18.4 & 15.1 & 58.6 \\
\hline Industrial wastewater release & 1.8 & 0.2 & 0.4 & 1.8 & 2.4 & 6.6 \\
\hline Leaching from forest soil & 0.1 & 0.1 & 0.1 & 0 & 0 & 0.4 \\
\hline Leaching from agricutural soil & 0.6 & 0.3 & 0.4 & 1.6 & 0.7 & 3.6 \\
\hline Input from upstream tributaries & 4.7 & 0 & 32.7 & 100.3 & 56.5 & 160.5 \\
\hline$\Sigma$ Inputs & 27.3 & 1.7 & 37.6 & 122.1 & 74.7 & 229.8 \\
\hline \multicolumn{7}{|l|}{ Riverine delivery at the outlet } \\
\hline $\mathrm{TN}$ & 10.0 & 1.3 & 21.6 & 71.2 & 59.2 & 129.5 \\
\hline Retention & 17.3 & 0.4 & 16.0 & 51.0 & 15.5 & 100.3 \\
\hline Retention/input (\%) & 63.5 & 24.3 & 42.6 & 41.7 & 20.7 & 43.6 \\
\hline
\end{tabular}

The budget is also indicated for the whole RRD 
the Bui sub-basin, with a high population density $\left(1,751\right.$ inhabitants $\mathrm{km}^{-2}$, the highest among all the other sub-basins) and intensive livestock farming, must import a large amount of agricultural products (production is $40.4 \times 10^{6} \mathrm{~kg} \mathrm{~N}_{\text {year }}{ }^{-1}$ and consumption is $45.5 \times 10^{6} \mathrm{~kg} \mathrm{~N}_{\text {year }}{ }^{-1}$, i.e., a difference of $5 \times 10^{6} \mathrm{~kg} \mathrm{~N}_{\text {year }}{ }^{-1}$ ) and is therefore a net importer of agricultural products. The large amount of wastewater produced in the Bui basin results in low oxygenation of many rivers and their sediments, which explains the rather high denitrification during transfer in the drainage network, compared with that in the Boi sub-basin (Fig. 4a, b). Finally, the riverine export from the Bui sub-basin amounts to $10 \times$ $10^{6} \mathrm{~kg} \mathrm{~N}$ year $^{-1}$ (about half coming from upstream influent Red River water through the Nhue and Chau rivers), while the corresponding figure is $1.3 \times 10^{6}$ $\mathrm{kg} \mathrm{N}_{\text {year }}{ }^{-1}$ from the Boi sub-basin. From the total nitrogen inputs to the basin, only 13 and $22 \%$ are delivered at the outlet of the Boi and Bui respectively. The budgets for the drainage network itself show a retention ranging from $48 \%$ in the Boi to $63 \%$ in the Bui (Table 4). These figures show the very high $\mathrm{N}$ retention capacity of both the delta's soils and hydrosystems.

The SS budget in the delta also shows a strikingly high retention (see Fig. 1c). Of the $23,630 \times 10^{6} \mathrm{~kg}$ SS year ${ }^{-1}$ entering the delta, only $5,800 \times 10^{6} \mathrm{~kg}$ SS year ${ }^{-1}$ is delivered to the coastal zone, i.e., a retention of about $75 \%$ (from 51 to $86 \%$ in the Bui and Lower RR estuary sub-basins, respectively). Retention in the three major branches of the delta

Table 5 Phosphorus budgets of the sub-basins of the RRD (Units are $10^{6} \mathrm{~kg}^{\mathrm{TP}}$ year ${ }^{-1}$ )

\begin{tabular}{|c|c|c|c|c|c|c|}
\hline $\mathrm{TP}, 10^{6} \mathrm{~kg} \mathrm{year}^{-1}$ & Bui SB & Boi SB & Estuary SB & Lower Red River SB & Duong SB & Total RRD \\
\hline Area $\left(\mathrm{km}^{2}\right)$ & $2,751.0$ & 2,473 & 1,413 & 4,773 & 2,902 & 14,312 \\
\hline \multicolumn{7}{|l|}{ Soil system } \\
\hline \multicolumn{7}{|l|}{ Atmospheric deposition } \\
\hline Forest & 0.0 & 0.1 & 0.0 & 0.0 & 0.0 & 0.1 \\
\hline Agriculture & 0.1 & 0.1 & 0.1 & 0.3 & 0.2 & 0.7 \\
\hline Fertilizer application & 10.1 & 4.2 & 5.6 & 22.9 & 11.1 & 54.0 \\
\hline \multicolumn{7}{|l|}{ Cattle farming } \\
\hline Meat and dairy production & 0.5 & 0.1 & 0.1 & 0.8 & 0.6 & 2.1 \\
\hline Excretion & 3.4 & 1.6 & 1.3 & 5.7 & 3.7 & 15.8 \\
\hline Grazing and feed consumption & 4.1 & 1.5 & 1.7 & 9.2 & 4.8 & 21.3 \\
\hline \multicolumn{7}{|l|}{ Agriculture and food balance } \\
\hline Agricultural production & 6.5 & 2.5 & 3.5 & 15.2 & 7.1 & 34.8 \\
\hline Net commercial export & -1.0 & 0.5 & 0.9 & 2.0 & -0.6 & 1.8 \\
\hline Human consumption & 3.4 & 0.5 & 0.9 & 4.0 & 3.0 & 11.7 \\
\hline \multicolumn{7}{|l|}{ Hydrosystem } \\
\hline \multicolumn{7}{|l|}{ Inputs to the hydrosystem } \\
\hline Domestic wastewater release & 3.2 & 0.3 & 0.6 & 2.9 & 2.4 & 9.5 \\
\hline Industrial wastewater release & 0.5 & 0.1 & 0.1 & 0.5 & 0.7 & 1.9 \\
\hline Leaching from forest soil & 0.0 & 0.1 & 0.0 & 0.0 & 0.0 & 0.1 \\
\hline Leaching from agricutural soil & 0.6 & 0.1 & 0.1 & 0.4 & 0.2 & 0.8 \\
\hline Input from upstream tributaries & 1.4 & 0.0 & 13.0 & 36.1 & 20.1 & 57.1 \\
\hline$\Sigma$ Inputs & 5.7 & 0.6 & 13.8 & 39.9 & 23.4 & 69.4 \\
\hline \multicolumn{7}{|l|}{ Riverine delivery at the outlet } \\
\hline Particulate P & 0.1 & 0.2 & 1.5 & 14.2 & 6.7 & 11.6 \\
\hline Total P & 0.9 & 0.2 & 5.2 & 26.8 & 11.9 & 31.5 \\
\hline Retention & 4.8 & 0.4 & 8.6 & 13.1 & 11.6 & 37.9 \\
\hline Retention/input (\%) & 84.1 & 60.4 & 62.3 & 32.9 & 49.4 & 54.6 \\
\hline
\end{tabular}

The budget is also indicated for the whole RRD 
amounts to 61,53 , and $86 \%$ in the Duong, lower Red River, and Day estuary sub-basins, respectively. This retention of suspended solid is necessarily accompanied by a corresponding retention of particulate nutrients.

At the scale of the whole delta (Fig. 4a), the striking feature is that although the total amount of $\mathrm{N}$ brought into the delta area as fertilizers, $\mathrm{N}_{2}$ fixation, atmospheric deposition and net import of food and feed (i.e., a total of $189 \times 10^{6} \mathrm{~kg} \mathrm{~N}$ year ${ }^{-1}$ ) represents more than the load of the Red River at the outlet of the upstream basin (i.e., $16010^{6} \mathrm{~kg} \mathrm{~N}_{\text {year }}{ }^{-1}$ ), the amount discharged at the outlets of the delta (i.e., 130 $10^{6} \mathrm{~kg} \mathrm{~N}$ year $^{-1}$ ) is approximately $20 \%$ lower. Whatever the uncertainty on the different terms of our budget can be, a robust conclusion is that more than half the total amount of nitrogen brought into the delta from the upstream catchment and human activity is eliminated or retained before reaching the sea. Waterlogged delta soils and the poorly oxygenated water of a large part of the drainage network both contribute to storing or eliminating the total $\mathrm{N}$ loading, thus acting as a rather efficient filter for anthropogenic $\mathrm{N}$ inputs.
The same appears true for the P budget (Fig. 4b). In spite of a large input of $\mathrm{P}$ as fertilizers (estimated to $55 \times 10^{6} \mathrm{~kg} \mathrm{P}$ year $^{-1}$ based on data on agricultural practices) and manure (estimated to $21 \times$ $10^{6} \mathrm{~kg} \mathrm{P}$ year ${ }^{-1}$ based on livestock census), largely in excess over the crop requirements (estimated to $35 \times 10^{6} \mathrm{~kg} \mathrm{P}$ year ${ }^{-1}$ ), export by leaching and erosion from the delta area appears very low based on our estimates of runoff $\left(1 \times 10^{6} \mathrm{~kg} \mathrm{P}\right.$ year $\left.^{-1}\right)$. Even if the latter is rather imprecise, the conclusion that a large fraction $\left(41 \times 10^{6} \mathrm{~kg} \mathrm{P}_{\text {year }}{ }^{-1}\right)$ of $\mathrm{P}$ brought in excess of crop uptake is stored in the soils is robust. Such high rates of $\mathrm{P}$ accumulation, which are equivalent to $28 \mathrm{~kg} \mathrm{P} \mathrm{ha}{ }^{-1}$ year $^{-1}$, are not unusual in European intensive agricultural areas, like in the Netherlands (Isermann 2007). Wastewater discharge is the most significant $\mathrm{P}$ source for surface water and amounts to $11 \times 10^{6} \mathrm{~kg} \mathrm{P}$ year $^{-1}$, which adds to the $57 \times 10^{6} \mathrm{~kg} \mathrm{P}$ year ${ }^{-1}$ coming from the upstream Red River watershed. The total discharge at the delta outlets is $32 \times 10^{6} \mathrm{~kg} \mathrm{P}$ year ${ }^{-1}$, thus showing retention of more than $50 \%$. As $\mathrm{P}$ is dominated by particulate forms and dissolved $\mathrm{P}$ is known to be easily exchangeable from the dissolved

Table 6 Silica budgets of the sub-basins of the RRD (Units are $10^{6} \mathrm{~kg} \mathrm{TSi} \mathrm{year}^{-1}$ )

\begin{tabular}{|c|c|c|c|c|c|c|}
\hline $\mathrm{TSi}, 10^{6} \mathrm{~kg}_{\text {year }}{ }^{-1}$ & Bui SB & Boi SB & Estuary SB & Lower Red River SB & Duong SB & Total RRD \\
\hline Area $\left(\mathrm{km}^{2}\right)$ & 2,751 & 2,473 & 1,413 & 4,773 & 2,902 & 14,312 \\
\hline \multicolumn{7}{|l|}{ Soil system } \\
\hline Fertilizer application & 0.00 & 0.00 & 0.00 & 0.00 & 0.00 & 0.00 \\
\hline \multicolumn{7}{|l|}{ Agriculture and food balance } \\
\hline Agricultural production & 0.20 & 0.10 & 0.10 & 0.60 & 0.30 & 1.3 \\
\hline Grazing and feed consumption & 0.00 & 0.00 & 0.10 & 0.10 & 0.10 & 0.3 \\
\hline Human consumption & 0.20 & 0.00 & 0.10 & 0.20 & 0.20 & 0.70 \\
\hline Net commercial export & 0.00 & 0.10 & 0.10 & 0.20 & 0.00 & 0.4 \\
\hline \multicolumn{7}{|l|}{ Hydrosystem } \\
\hline \multicolumn{7}{|l|}{ Inputs to the hydrosystems } \\
\hline Wastewater release & 0.30 & 0.00 & 0.10 & 0.30 & 0.40 & 1.50 \\
\hline Leaching from soil & 3.5 & 3.2 & 2.1 & 7.7 & 3.6 & 20.0 \\
\hline Total Input from upstream tributaries & 14.7 & 0 & 88.9 & 303.1 & 172.6 & 485.6 \\
\hline$\Sigma$ Input & 18.5 & 3.2 & 91 & 311.1 & 176.6 & 507.1 \\
\hline \multicolumn{7}{|l|}{ Riverine delivery at the outlet } \\
\hline Amorphous Silica & 0.40 & 0.40 & 3.60 & 34 & 16.1 & 27.8 \\
\hline Total Silica & 16.70 & 3.10 & 86 & 281.4 & 170.5 & 463.9 \\
\hline Retention & 1.8 & 0.2 & 0.5 & 29.7 & 6.2 & 43.2 \\
\hline Retention/Input (\%) & 9.9 & 4.9 & 5.5 & 9.5 & 3.5 & 8.5 \\
\hline
\end{tabular}

The budget is also indicated for the whole RRD 


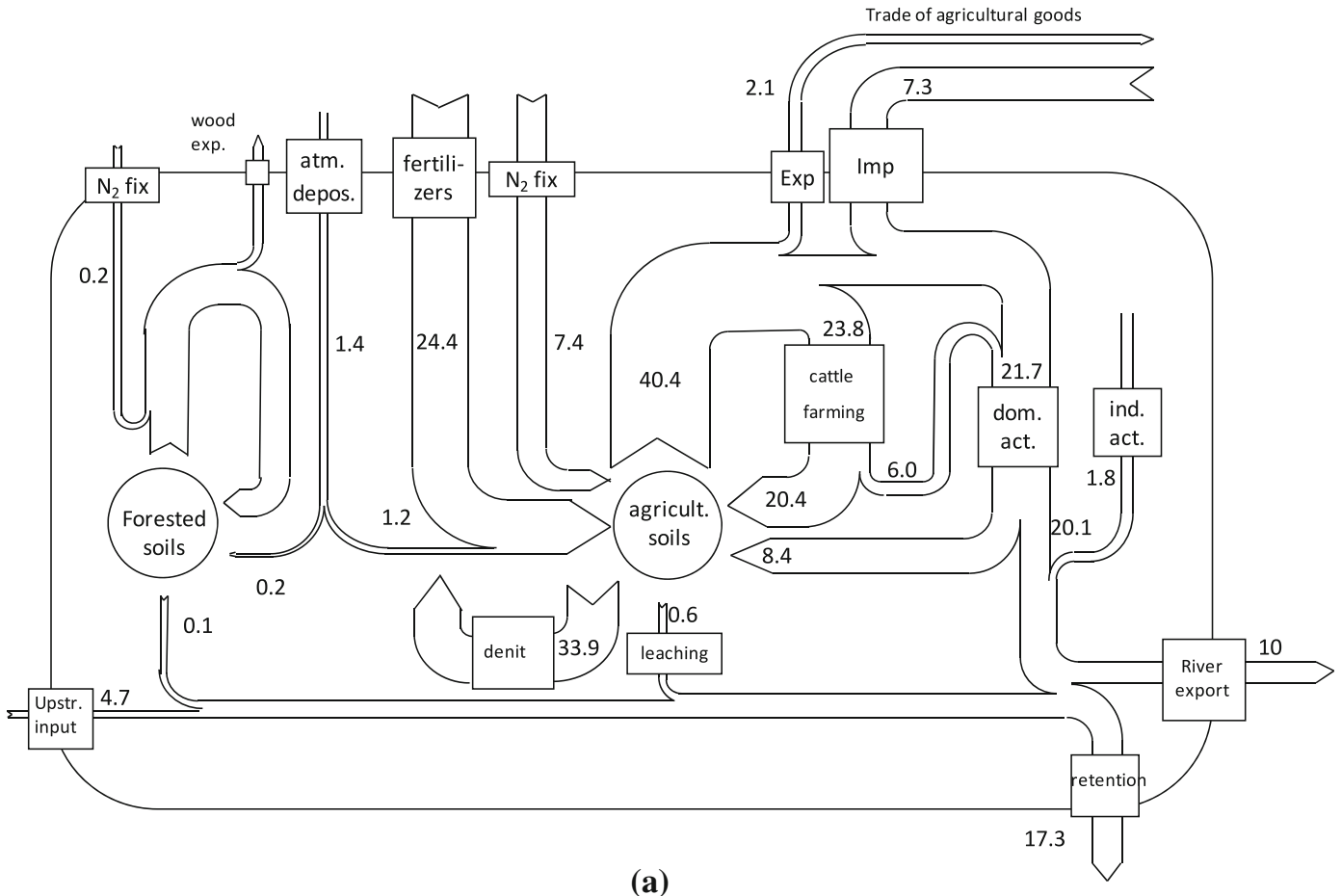

(a)

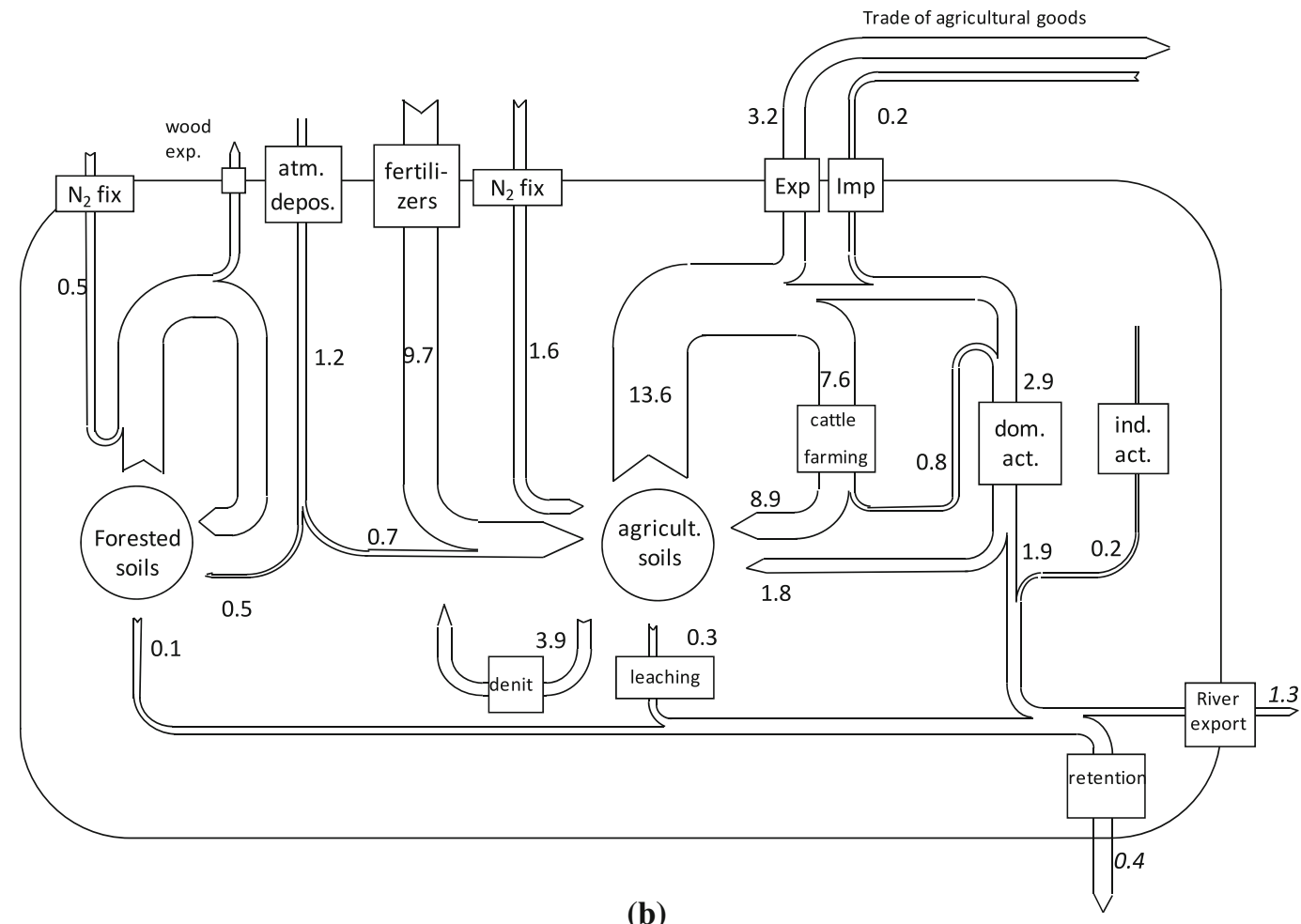

Fig. 3 a Nitrogen budget for the Bui basin $\left(2751 \mathrm{~km}^{2}\right.$ ), dominated by agricultural soil for the year 2006 (unit: $10^{6} \mathrm{~kg} \mathrm{year}^{-1}$ ). b Nitrogen budget for the Boi basin $\left(2473 \mathrm{~km}^{2}\right.$ ) dominated by forest for the year 2006 (unit: $10^{6} \mathrm{~kg} \mathrm{year}^{-1}$ ) 
to the particulate phase (Némery and Garnier 2007a, b; House 2003), sedimentation probably plays the major role here, although uptake by algae and macrophytes cannot be excluded. The highest retention is observed in the Bui $(>80 \%)$. Thanks to this high retention rate in the most populated sub-basin, not all $\mathrm{P}$ brought from domestic effluents reaches the coastal zone.

The budget of $\mathrm{Si}$ transformation (Fig. 4c) is simpler than that of $\mathrm{N}$ and $\mathrm{P}$, as the anthropogenic contribution to the $\mathrm{Si}$ cycle is much less significant. Human point inputs of $\mathrm{Si}$ are indeed small when compared with $\mathrm{N}$ and P. For the hydrological system, we have measured $\mathrm{Si}$ under its two major forms, dissolved and particulate amorphous $\mathrm{Si}$. It is worth mentioning that on a global scale the ASi of only a few rivers have been documented, except for some of the rivers of the north Atlantic, the Seine (Garnier et al. 2002; Sferratore et al. 2006) and the Scheldt (Struyf et al. 2006) and those of the Baltic Sea, e.g., the Oder (Pastuszak et al. 2008). Since Si originates essentially from phytoliths eroded from the watershed soils, the RRD, with its flat topology and a low rate of erosion (Mai 2007), represents a rather low source of ASi (Table 6). ASi originates mainly from the tributaries, upstream of the delta. The particulate $\mathrm{Si}$ at the outlet of the RRD averages $6 \%$ of total $\mathrm{Si}$, while it averages $16 \%$ at the inlet of the delta, implying that from the $113 \times 10^{6} \mathrm{~kg} \mathrm{ASi}$ year $^{-1}$ which enters the delta, only $28 \times 10^{6} \mathrm{~kg} \mathrm{ASi} \mathrm{year}^{-1}$ is delivered to the sea. This significant ASi retention process through sedimentation is, however, partly compensated by dissolution, as the estimated export of DSi at the outlets of the delta $\left(436 \times 10^{6} \mathrm{~kg}\right.$ DSi year ${ }^{-1}$ ) is higher than the import from the upstream Red River basin $\left(366 \times 10^{6} \mathrm{~kg}\right.$ DSi year $^{-1}$ ) (Fig. 4c). In total, the overall $\mathrm{Si}$ retention amounts to $36 \times 10^{6} \mathrm{~kg} \mathrm{DSi} \mathrm{year}^{-1}$, i.e. only $8.5 \%$ of the total inputs to the delta area. Here again, the conclusion of a low retention by the delta of the upstream silica inputs is robust in spite of the $25 \%$ uncertainty on the budget terms.

\section{Eutrophication potential}

It is now recognized that the basic cause of coastal zone eutrophication is related not only to the general nutrient enrichment of the marine system, but also to the imbalance in the delivery of $\mathrm{N}$ and $\mathrm{P}$ with respect to
Si (Billen and Garnier 1997, 2007; Turner et al. 2006; Conley 2002). Based on the ratios corresponding to the physiological needs of the algae (Redfield et al. 1963), Billen and Garnier (2007) have defined the ICEP (indicator of coastal eutrophication potential) in order to provide insight into the risk of eutrophication at the coastal zone due to riverine nutrient delivery. Negative ICEP corresponds to situations where $\mathrm{Si}$ is delivered in excess over $\mathrm{P}$ or $\mathrm{N}$, thus preventing Si limitation of marine diatoms, which could result in the proliferation of non siliceous, harmful bloom-forming algae. The risk of eutrophication increases with increasing positive ICEP (Billen and Garnier 2007). Both N-ICEP and P-ICEP can be defined (Garnier et al. 2010a, b) according to whether $\mathrm{N}$ or $\mathrm{P}$ is supposed to be the most limiting nutrient:N-ICEP $=[\mathrm{NFlx} /$ $(14 * 16)-\mathrm{SiFlx} /(28 * 20)] * 106 * 12 \quad$ if $\mathrm{N} / \mathrm{P}<16$ $(\mathrm{N}$ limiting $) \mathrm{P}-\mathrm{ICEP}=[\mathrm{PFlx} / 31-\mathrm{SiFlx} /(28 * 20)]$ $* 106 * 12$ if $\mathrm{N} / \mathrm{P}>16$ (Plimiting)where ICEP is expressed in $\mathrm{kg} \mathrm{C} \mathrm{km}^{-2} \mathrm{day}^{-1}$, NFlx, PFlx and SiFlx are, respectively, the mean specific fluxes of total nitrogen, phosphorus and dissolved silica (expressed as $\mathrm{kg} \mathrm{km}^{-2}$ day $^{-1}$ ). As defined, ICEP does not take into account the specific conditions determining the response of the coastal zone into which the river is discharging (see Rabouille et al. 2008; Diaz and Rosenberg 2008), but simply represents the potential impact of the riverine fluxes.

At the inlet of the RRD (Red River at SonTay), negative values are calculated for the N-ICEP $\left(-3.1 \mathrm{~kg} \mathrm{C} \mathrm{km}{ }^{-2} \mathrm{day}^{-1}\right)$ and positive for the P-ICEP (21.9 $\mathrm{kg} \mathrm{C} \mathrm{km}^{-2} \mathrm{day}^{-1}$ ) (Table 7). At the outlet of the delta, both the N-ICEP and P-ICEP are reduced, to $-5.1 \mathrm{~kg} \mathrm{C} \mathrm{km}^{-2}$ day $^{-1}$ for N-ICEP and $3.9 \mathrm{~kg} \mathrm{C} \mathrm{km}^{-2}$ day $^{-1}$ for P-ICEP. This indicates that the delta has quite a positive effect in counteracting coastal zone eutrophication, owing to the abovementioned efficient filtering effect of the delta toward $\mathrm{N}$ and $\mathrm{P}$, while $\mathrm{Si}$ fluxes are minimally affected. Without this effect, the risk of eutrophication of the Tonkin Bay would have been significant as evidenced by positive N-ICEP and P-ICEP values (Table 7). Instead, the RRD coastal zone appears still N-limited and shows a $\mathrm{P}$ level close to the physiological equilibrium with regard to $\mathrm{Si}$, thus not subject to severe eutrophication. It could be however that the protecting role of the delta might not be sufficient in the future with growing population, further agriculture intensification in the delta area, and a reduction 

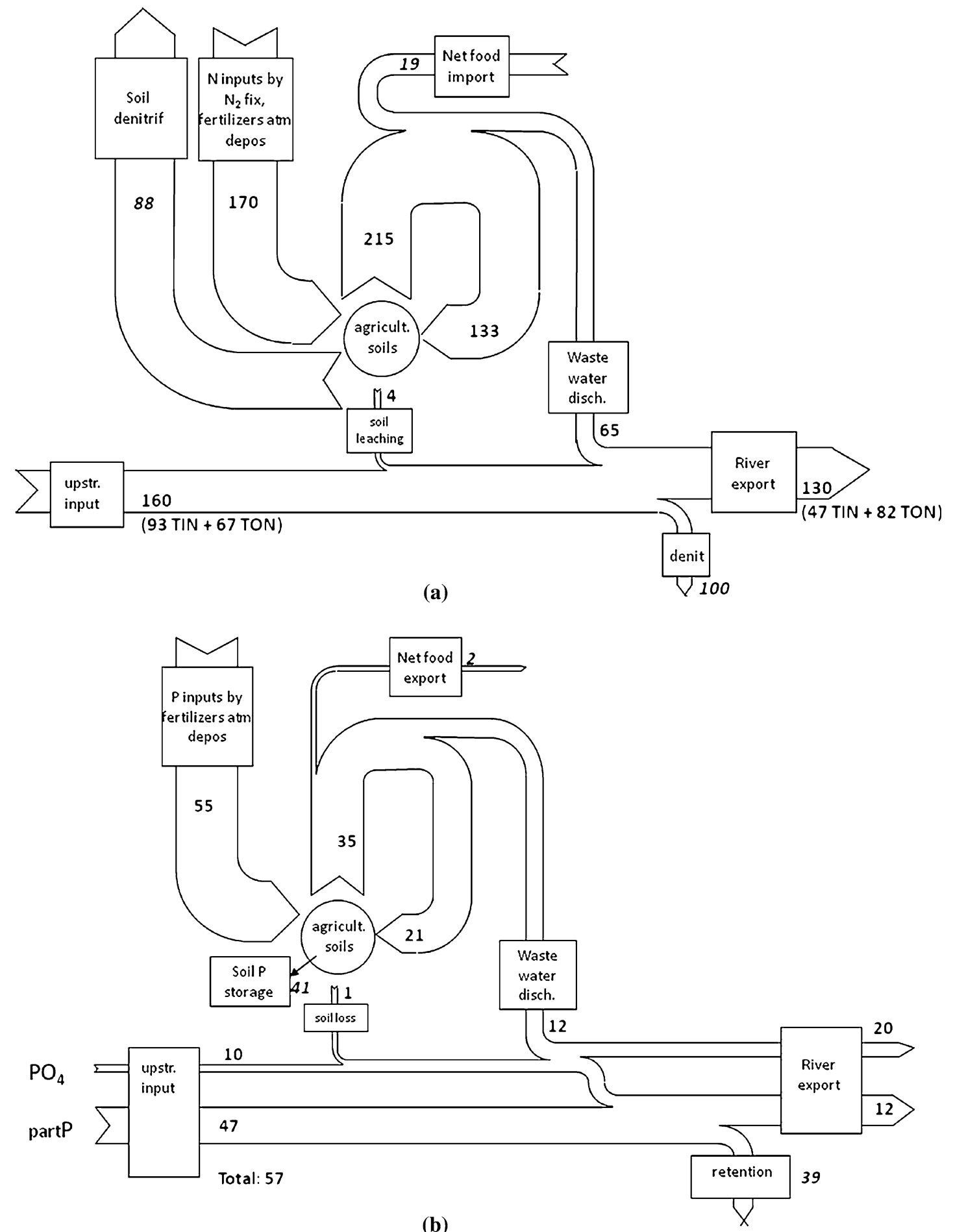

Fig. 4 a Summarized budget for the whole delta $\left(14,312 \mathrm{~km}^{2}\right)$ : $\mathrm{N}$ (2006) in $10^{6} \mathrm{~kg} \mathrm{~N}$ year $^{-1}$ (Figures in italic are estimated by difference, the others are independent estimations). b Summarized budget for the whole delta $\left(14,312 \mathrm{~km}^{2}\right)$ : P (2006) in $10^{6}$ $\mathrm{kg} \mathrm{P} \mathrm{year}^{-1}$ (Figures in italic are estimated by difference, the

others are independent estimations). c Summarized budget for the whole delta $\left(14,312 \mathrm{~km}^{2}\right)$ : Si (2006) in $10^{6} \mathrm{~kg} \mathrm{Si} \mathrm{year}^{-1}$ (Figures in italic are estimated by difference, the others are independent estimations) 


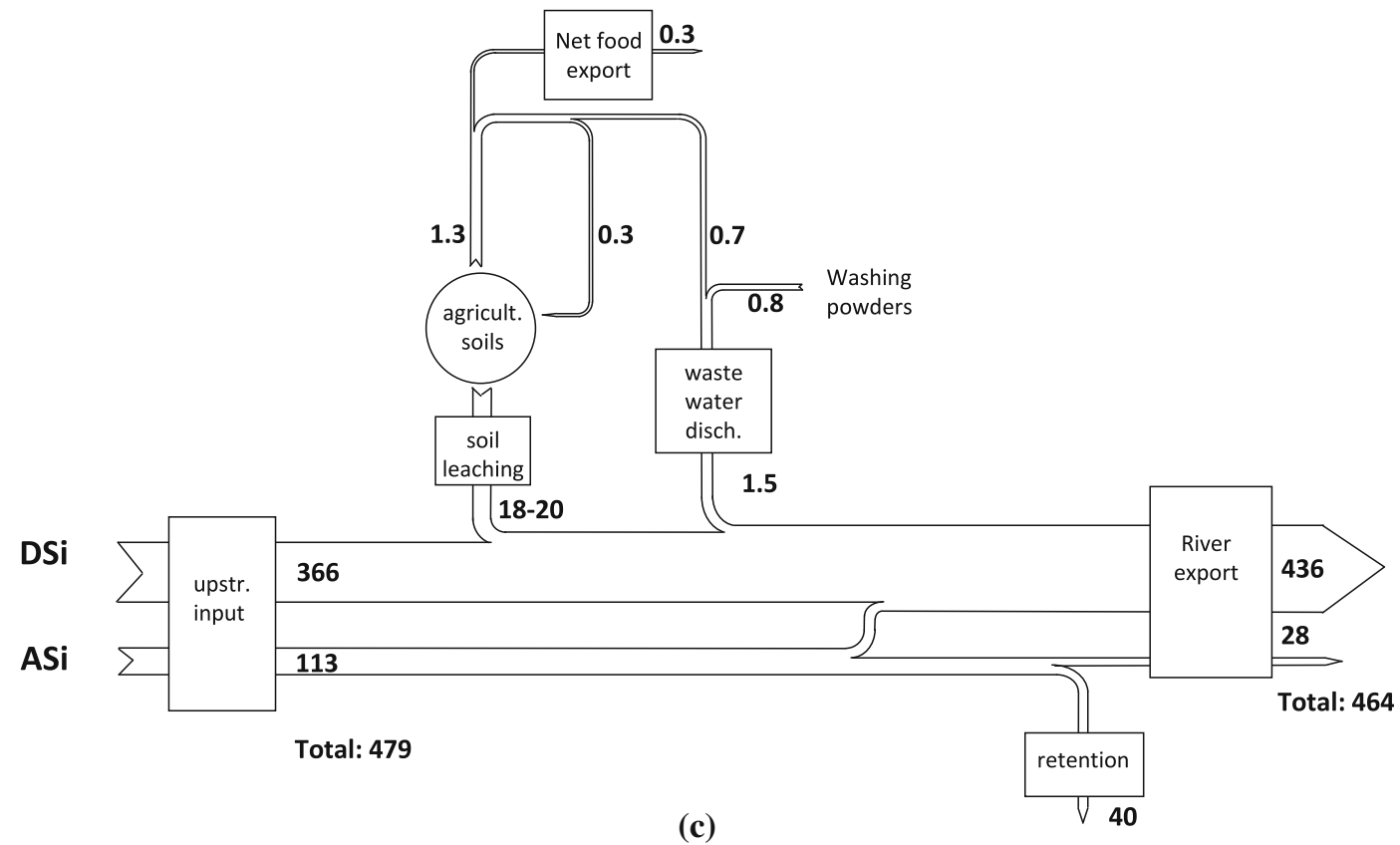

Fig. 4 continued

of the upstream $\mathrm{Si}$ inputs due to the planned construction of two additional large dams on the upper course of the Red River and one on its tributaries (Li et al. 2007; Humborg et al. 2006, 2008; Yunev et al. 2007). Also, the high amounts of $P$ accumulated in agricultural soils and river sediments are a threat for the future water quality in this region of the world (Sharpley et al. 2001; Ulén and Kalisky 2005, House 2003).

\section{Comparison with other estuarine systems}

There are only very few estimates of the retention capacity of estuarine and deltaic systems on riverine $\mathrm{N}$, $\mathrm{P}$ and $\mathrm{Si}$ fluxes, allowing an assessment of their buffering role with respect to eutrophication potential.
The Danube delta studied by Raducu (2002) offers an interesting comparison. With a much lower population density than the RRD ( 90 vs. 1,160 inhabitants $\mathrm{km}^{-2}$ ), this system shows only respectively $7-10$ and $6-8 \%$ retention of the total inputs of $\mathrm{N}$ and $\mathrm{P}$ entering the delta, while DSi retention is about $20-30 \%$. In this case, the nutrient processing in the delta, although of relatively low extent, would tend to increase the risk of eutrophication. The case of the Seine estuary, recently studied from this respect by Garnier et al. (2010a, b) show a similarly limited effect of this highly perturbed micro-tidal estuarine system, with annual N, P and $\mathrm{Si}$ retention of 7, 31 and $4 \%$ respectively. Compared with these two systems, the RRD thus appears to have a much higher capacity for $\mathrm{N}$ and $\mathrm{P}$ retention while being less retentive towards silica fluxes. Further studies are
Table 7 Total riverine delivery in TN, TP, TSi and value of $\mathrm{N}$ - ICEP and $\mathrm{P}$ ICEP at the inlets and outlets of the RRD

The calculated flux and ICEP values as they would be in the absence of the delta drainage network retention is also indicated

\begin{tabular}{llll}
\hline & $\begin{array}{l}\text { Total delta } \\
\text { inlets }\end{array}$ & $\begin{array}{l}\text { Total delta } \\
\text { outlets }\end{array}$ & $\begin{array}{l}\text { Total delta outlets } \\
\text { without retention }\end{array}$ \\
\hline $\begin{array}{l}\text { Riverine delivery at the outlet } \\
\mathrm{TN}, 10^{6} \mathrm{~kg} \mathrm{~N} / \text { year }\end{array}$ & 160 & & \\
$\mathrm{TP}, 10^{6} \mathrm{~kg} \mathrm{P} / \mathrm{year}$ & 57 & 129.5 & 230 \\
$\mathrm{TSi}, 10^{6} \mathrm{~kg} \mathrm{Si} / \mathrm{year}$ & 479 & 31.5 & 69 \\
$\mathrm{~N}-\mathrm{ICEP}, \mathrm{gC} / \mathrm{km}^{2} /$ day & -3.1 & 463 & 507 \\
$\mathrm{P}-\mathrm{ICEP}, \mathrm{gC} / \mathrm{km}^{2} /$ day & 21.9 & -5.1 & 2.5 \\
\hline
\end{tabular}


required to allow generalization about the role of deltaic and estuarine systems as buffer zones between riverine and marine systems.

Acknowledgments The work was supported by the French ANR program Day River, by the Vietnamese Academy of Science and Technology (VAST, Vietnam), the Centre National de la Recherche Scientifique (CNRS, France), the Institute of Research for Development (IRD, France). Many thanks are due to Prof. Georges Vachaud who coordinated the ANR programme. The PhD thesis of Luu Thi Nguyet Minh is supported by a scholarship from the French Embassy in Vietnam and by a cooperation agreement between Pierre and Marie Curie University (UPMC) and the Vietnamese Academy of Science and Technology (VAST). The Federation Ile-deFrance for Research on the Environment (FIRE FR3020 CNRS \& UPMC) is greatly acknowledged for its interdisciplinary research framework and its role in the signature of the cooperation agreements between UPMC and VAST.

Open Access This article is distributed under the terms of the Creative Commons Attribution Noncommercial License which permits any noncommercial use, distribution, and reproduction in any medium, provided the original author(s) and source are credited.

\section{References}

Afnor (1982) Dosage des orthophosphates, des polyphosphates et du phosphore total (méthode spectrométrique) norme AFNOR T90-023 de septembre 1982

Akaselsson C, Westling O, Sverdrup H, Gundersen P (2007) Nutrient and carbon budgets in forest soils as decision support in sustainable forest management. For Ecol Manag 238:167-174

Baker AR, Weston K, Kelly SD, Voss M, Streu P, Cape JN (2007) Dry and wet deposition of nutrients from the tropical Atlantic atmosphere: links to primary productivity and nitrogen fixation. Deep-sea Res I 54:1704-1720

Bange WH (2000) It's not a gas. Nature 408:301-302

Billen G, Garnier J (1997) The Phison River Plume: coastal eutrophication in response to changes in land use and water management in the watershed. Aquat Microb Ecol $13: 3-17$

Billen G, Garnier J (2007) River basin nutrient delivery to the coastal sea: assessing its potential to sustain new production of non-siliceous algae. Mar Chem 106:148-160

Billen G, Garnier J, Rousseau V (2005) Nutrient fluxes and water quality in the drainage network of the Scheldt basin over the last 50 years. Hydrobiologia 540:47-67

Billen G, Garnier J, Némery J, Sebilo M, Sferratore A, Barles S, Benoit P, Benoit M (2007) A long-term view of nutrient transfers through the Seine river continuum. Sci Total Environ 375:80-97

Boyer EW, Howarth RW (2008) Nitrogen Fluxes from Rivers to the Coastal Oceans. Chapter 36, in: Nitrogen in the marine environment, Elsevier, pp 1565-1584. doi:10. 1016/B978-0-12-372522-6.00036-0
Boyer EW, Goodale CL, Jaworski NA, Howarth RW (2002) Anthropogenic nitrogen sources and relationships to riverine nitrogen export in the northeastern USA. Biogeochemistry 57(58):137-169

Buranapratheprat A, Testuo Y, Thanomsak B, Pichan S (2002) Seasonal variations in Inorganic Nutrients Budgets of the Bankapong Estuary, Thailand. J Oceanogr 58:557-564

Chapin F, Matson P, Mooney H (2002) Principles of terrestrial ecosystem ecology. Springer, New York, $450 \mathrm{pp}$

Conley DJ (1998) An interlaboratory comparison for the measurement of biogenic silica in sediments. Mar Chem 63:39-48

Conley DJ (2002) Terrestrial ecosystem and the global biogeochemical silica cycle. Glob Cycles 16:1121-1129

Conley DJ, Kilham SS, Theriot EC (1989) Differences in silica content between marine and freshwater diatoms. Limnol Oceanogr 34:205-213

Cordell D, Drangert J-O, White S (2009) The story of phosphorus: global food security. Glob Environ Change 19: 292-305

Crutzen PJ, Ehhalt DH (1977) Effects of nitrogen fertilizers and combustion on the stratospheric ozone layer. Ambio 6:112-117

Cugier P, Billen G, Guillaud JF, Garnier J, Ménesguen A (2005) Modelling eutrophication of the Seine Bight under present, historical and future Seine river nutrient loads. J Hydrol 304:381-396

Diaz RJ, Rosenberg R (2008) Spreading dead zones and consequences for marine ecosystems. Science 321:926-929. doi:10.1126/science. 1156401

Eberlein K, Katter G (1984) Automatic method for the determination of orthophosphate and dissolved phosphorus in the marine environment. Fresenius $\mathrm{Z}$ Anal Chem 326: 354-357

Faerge J, Magid J, Penning de Vries FWT (2001) Urban nutrient balance for Bankok. Ecol Model 139:63-74

FAO (2003) Assessment of soil nutrient balance: approaches and methodologies. FAO Fertilizer and Plant Nutrition Bulletin 14, Rome, $100 \mathrm{pp}$

FAO (2005) Bilan des éléments nutritifs du sol à différentes échelles. Application des méthodes intermédiaires aux réalités africaines. FAO Fertilizer and Plant Nutrition Bulletin 15, Rome, $158 \mathrm{pp}$

FAO (2006) Fertilizer use by crop. FAO Fertilizer and Plant Nutrition Bulletin 17, Rome, 124 pp

Galloway JN, Cowling EB (2002) Reactive nitrogen and the world: 200 years of change. Ambio 31(2):64-71

Garnier J, Leporcq B, Sanchez N, Philippon X (1999) Biogeochemical budgets in three large reservoirs of the Seine basin (Marne, Seine and Aube reservoirs). Biogeochemistry 47:119-146

Garnier J, Billen G, Hannon E, Fonbonne S, Videnina Y, Soulie M (2002) Modelling the transfer and retention of nutrients in the drainage network of the Danube river. Estuar Coast Shelf Sci 54:285-308

Garnier J, Billen G, Némery J, Sebilo M (2010a) Transformations of nutrients $(\mathrm{N}, \mathrm{P}, \mathrm{Si})$ in the turbidity maximum zone of the Seine estuary and export to the sea. Estuar Coast Shelf Sci 90:129-141

Garnier J, Beusen A, Thieu V, Billen G, Bouwman L (2010) $\mathrm{N}: \mathrm{P}:$ Si nutrient export ratios and ecological consequences 
in coastal seas evaluated by the ICEP approach. Glob Biogeochem Cycles 24. doi:10.1029/2009GB003583

General Statistic Office (2006) Statistical handbook of Vietnam. Statistical Publisher, Hanoi

House AW (2003) Geochemical cycling of phosphorus in rivers. Appl Geochem 18:739-748

Howarth RW, Billen G, Swaney D et al (1996) Regional nitrogen budgets and riverine $\mathrm{N} \& \mathrm{P}$ fluxes for the drainages to the North Atlantic Ocean: natural and human influences. Biogeochemistry 35:75-139

Humborg C, Pastuszak M, Aigars J, Siegmund H, Morth CM, Ittekkot V (2006) Decreased silica land-sea fluxes through damming in the Baltic Sea catchment-significance of particle trapping and hydrological alterations. Biogeochemistry 77:265-281

Humborg C, Smedberg E, Rodriguez Medina M, Mörth CM (2008) Changes in dissolved silicate loads to the Baltic Sea-the effects of lakes and reservoirs. J Mar Syst 73:223-235

IMHE - MONRE (1996-2006) Vietnamese Ministry of Environment and Natural Resources. Annual report on hydrological observation in Vietnam

Isermann K (2007) Phosphorus balances in Europe and implications for diffuse pollution policy. In: Heckrath G, Rubæk GH, Kronvang B (eds) Diffuse phosphorus loss: risk assessment, mitigation options and ecological effects in river basins. 5th International phosphorus workshop (IPW5) DJF Plant Science 130. Faculty of Agricultural Sciences, Tjele, pp 91-94

Jones MN (1984) Nitrate reduction by shaking with cadmium, alternative to cadmium columns. Water Res 18:643-646

Justic D, Rabalais NN, Turner RE (2002) Modeling the impacts of decadal changes in riverine nutrient fluxes on coastal eutrophication near the Mississippi River Delta. Ecol Model 152:33-46

Knowler D (2007) Estimation of a stock-recruitment relationship for Black Sea anchovy (Engraulis encrasicolus) under the influence of nutrient enrichment and the invasive comb-jelly, Mnemiopsis leidyi. Fish Res 84(3): 275-281

Kurosawa K, Do NH, Nguyen HT, Ho TLT, Tran TLH, Nguyen TC, Egashira K (2006) Temporal and spatial variations of inorganic nitrogen levels in surface and groundwater around Hanoi, Vietnam. Commun Soil Sci Plant Anal 37:403-415

Le TPQ, Billen G, Garnier J, Théry S, Fézard C, Chau VM (2005) Nutrient (N, P) budgets for the Red River basin (Vietnam and China). Glob Biogeochem Cycles 19:GB2022. doi:10.1029/2004GB002405

Le TPQ, Billen G, Garnier J, Théry S, Ruelland D, Nghiem XA, Chau VM (2010) Nutrient (N, P, Si) transfers in the subtropical Red River system (China and Vietnam): modelling and budget of nutrient sources and sinks. Asian Earth Sci 37:259-274

Li M, Xu K, Watanabe M, Chen Z (2007) Long-term variations in dissolved silicate, nitrogen, and phosphorus flux from the Yangtze River into the East China Sea and impacts on estuarine ecosystem Estuarine. Coast Shelf Sci 71:3-12

Luu TNM, Garnier J, Billen G, Orange D, Néméry J, Le TPQ, Tran HT, Le LA (2010) Hydrological regime and water budget of the Red River Delta (Northern Vietnam). J Asian Earth Sci 37(3):219-228

Mai VT (2007) Soil erosion and nitrogen leaching in northern Vietnam: experimentation and modelling. $\mathrm{PhD}$ thesis, Wageningen University, Wageningen, The Netherlands, $182 \mathrm{pp}$

Moon S, Huh Y, Qin J, Nguyen VP (2007) Chemical weathering in the Hong (Red) River basin: rates of silicate weathering and their controlling factors. Geochim Cosmochim Acta 71(6):1411-1430

Némery J, Garnier J (2007a) Origin and fate of phosphorus in the Seine watershed (France): agricultural and hydrographic P budgets. J Geophys Res 112:G03012. doi: 10.1029/2006JG000331

Némery J, Garnier J (2007b) Dynamics of particulate phosphorus in the Seine estuary (France). Hydrobiologia 588:271-290

Ngo LL, Madsen H, Rosbjerg D (2007) Simulation and optimisation modelling approach for operation of the Hoa Binh reservoir, Vietnam. J Hydrol 336:269-281

Nguyen NS, Hua CT, Nguyen CH, Nguyen VT, Lang VK, Pham VN, Nguyen VT (1995) Case study report « Red River Delta, Vietnam », Project on integrated management of watersheds in relation to management and conservation of nearshore coastal and marine areas in East Asia Region, 78 pp

Nguyen VC, Do XS, Nguyen QT et al (2005) Elaboration d'un projet de préservation de l'environnement du bassin Nhué et Day. Rapport d'un projet national, 400 pp (in Vietnamese)

Pastuszak M, Conley DJ, Humborg C, Witek Z, Sitek S (2008) Silicon dynamics in the Oder estuary, Baltic Sea. J Mar Syst 73:250-262

Rabouille C, Conley DJ, Dai MH et al (2008) Comparison of hypoxia among four river-dominated ocean margins: the Changjiang (Yangtze), Mississippi, Pearl, and Rhône rivers. Cont Shelf Res 28(12):1527-1537

Raducu MC (2002) Transfert des nutriments dans le basin du Danube et apports à la Mer Noire: modélisation et bilans. Thèse de doctorat de l'Université Pierre et Marie Curie. Ecole Doctorale Géosciences et Ressources Naturelles, Paris

Ragueneau O, Treguer P (1994) Determination of biogenic silica in coastal waters: applicability and limits of the alkaline digestion method. Mar Chem 45:43-51

Ramade F (2009) Elément d'Ecologie. Ecologie fondamentale, Dunod, Paris, 690 pp

Redfield AC, Ketchum BH, Richard FA (1963) The influence of organisms on the composition of sea-water. In: Hill MN (ed) The sea. Wiley, New York, pp 12-37

Rodier J (1984) L'analyse de l'eau. 7ème édition. Dunot (ed), Paris, France, 1365 pp

Sferratore A, Garnier J, Billen G, Conley D, Pinault S (2006) Diffuse and point sources of Silica in the Seine River Watershed. Environ Sci Technol 40:6630-6635

Sharpley AN, McDowell RW, Kleinman PJA (2001) Phosphorus loss from land to water: integrating agricultural and environmental management. Plant Soil 237:287-307

Slawyck G, McIsaac JJ (1972) Comparison of two automated ammonium methods in a region of coastal upwelling. Deep-Sea Res 19:1-4 
Smil V (1999) Nitrogen in crop production: an account of global flows. Glob Biogeochem Cycles 13(2):647-662

Struyf E, Dausse A, Van Damme S et al (2006) Tidal marshes and biogenic silica recycling at the land-sea interface. Limnol Oceanogr 51:838-846

Thieu V, Billen G, Garnier J (2009) Nutrient transfer in three contrasting NW European watersheds: the Seine, Somme, and Scheldt Rivers. A comparative application of the Seneque/Riverstrahler model. Water Res 43(6):1740-1754

Tran TX (2007) Hydrological characteristic and water resources in Vietnam, Agricultural Editor Hanoi, 427 pp (in Vietnamese)

Tran HT, Tran T, Duong HS et al (2006) Final report on water quality modeling for the three river basins: Cau, NhueDay, Sai Gon-Dong Nai. National Institute of Meteorology, Hydrology and Environment, $240 \mathrm{pp}$

Trinh AD, Bonnet MP, Vachaud G, Chau VM, Prieur N, Vu DL, Le LA (2006) Biogeochemical modelling of Nhue River (Hanoi, Vietnam): practical identifiability analysis and parameters estimations. Ecol Model 193:182-204

Turner RE, Rabalais NN, Justic D (2006) Predicting summer hypoxia in the northern Gulf of Mexico: Riverine N, P and Si loading. Mar Pollut Bull 52:139-148

Ulén BM, Kalisky T (2005) Water erosion and phosphorus problems in an agricultural catchment-need for natural research for implementation of the EU Water Framework Directive. Environ Sci Policy 8:477-484
Van Drecht G, Bouwman, Knoop J, Beusen M, Meinardi CR (2003) Global modelling of the fate of nitrogen from point and nonpoint sources in soils, groundwater and surface water. Glob Biogeochem Cycles 17(4):1115-1120. doi: 10.1029/2003GB002060

Verhoff FH, Yaksich SM, Melfi DA (1980) River nutrient and chemical transport estimates. J Environ Eng Div ASCE 10:591-608

Vollenweider RA (1968) Scientific fundamentals of the eutrophication of lakes and flowing waters with particular reference to nitrogen and phosphorus as factors in eutrophication. Water Management Research. OECD, Paris. Tech. Rpt. DA 5/SCI/68.27, 250 pp

Wassmann P, Olli K (2004). Drainage basin nutrient inputs and eutrophication: an integrated approach. University of Troms $\emptyset$, Norway, 325 pp. www.ut.ee/olli/eutr/

Wetzel RG (1983) Limnology, 2nd edn. Saunders College Publishing, Philadelphia, $860 \mathrm{pp}$

Wosten JHM, Willigen P, Tri NH, Lien TV, Smith SV (2003) Nutrient dynamics in mangrove areas of the Red River Estuary in Vietnam. Estuar Coastal Shelf Sci 57:65-72

Yunev OA, Carstensen J, Moncheva S, Khaliulin A, Ærtebjerg G, Nixon S (2007) Nutrient and phytoplankton trends on the western Black Sea shelf in response to cultural eutrophication and climate changes. Estuar Coastal Shelf Sci 74:63-76 